STUDIA KATECHETYCZNE - tom 17/2021

DOI https://doi.org/10.21697/sk.2021.17.?

KS. MATEUSZ ADAMSKI

UKSW WARSZAWA

\title{
KATECHEZA W ŚWIECIE CYFROWYM. INKULTURACJA I JĘZYK W KULTURZE CYFROWEJ
}

Wśród współczesnych wyzwań, przed którymi staje katecheza jest - jak podaje Dyrektorium o Katechizacji - „cyfrowość”. Żadne z poprzednich dyrektoriów (DCG, DOK, PDK) nie poświęciło temu zagadnieniu tak wiele uwagi i wnikliwej oceny jak Dyrektorium obecne ${ }^{2}$. Wiąże się to oczywiście z konkretnym czasem,

1 DK 359.

2 W Directorium catechesticum generale opisywane zagadnienie zostało umieszczone w rozdziale IV: „Pomoce katechetyczne”, w podrozdziałach: „Pomoce audiowizulane”, „Środki masowego przekazu”, „Wychowanie zaprogramowane” (por. DOK 122-124). W pozostałych punktach dyrektorium znajdziemy pojedyncze wzmianki i odniesienia dotyczące tych pojęć. Ale już w $D y$ rektorium ogólnym o katechizacji poświęcono tym kwestiom o wiele więcej miejsca: zarówno w całym dokumencie, wzmiankując o przemianach kulturowych związanych z rozwojem technologii medialnej w poszczególnych punktach, odnoszących się do opisywanych zagadnień oraz w dwóch podrozdziałach zatytułowanych: „Środki masowego przekazu”, umieszczonych w części III: „Pedagogia wiary”, rozdziale II: „Elementy metodologii” (DOK 160-162), oraz w Części IV: „Adresaci katechezy”, rozdziale V: „Katecheza w kontekście społeczno-kulturowym” (DOK 209-210). Pokazuje to iż Dyrektorium ogólne o katechizacji dostrzegło w środkach społecznego przekazu nie tylko znaczenie metodologiczne, ale również kulturowe i społeczne, wpływające na samych adresatów katechezy. Dziwi zatem fakt, że w Dyrektorium katechetycznym Kościoła katolickiego w Polsce zagadnieniu „środków społecznej komunikacji” (PDK 48) poświęcono tylko dwa punkty (PDK 47-48), umieszczając je w Części I: „Katecheza w posłudze duszpasterskiej Kościoła”, rozdziale II: „Funkcje katechezy”, podrozdziale: „Katecheza jako nauczanie”, traktując te środki pod względem metodologicznym jako pomoce katechetyczne, nie dostrzegając jeszcze w Polsce przemian społeczno-kulturowych, o których już wiele pisało Dyrektorium ogólne o katechizacji. Oczywiście oba dyrektoria są ze sobą ściśle związane, niemniej można wysnuć wniosek, iż w Polsce w 2001 roku jeszcze nie zauważano tak wielkiego wpływu środków masowego przekazu, które stałoby u podstaw przemian społeczno-kulturowych zauważanych już w innych krajach i to stało się przyczyną nie poświęcenia w owym dyrektorium zbyt wielkiej uwagi tym przemianom. Na tle wspomnianych trzech dyrektoriów znacząco wy różnia się Dyrektorium o katechizacji, które nie tylko poświęca wiele punktów swej refleksji środkom społecznego przekazu i powiązanych z nimi kwestii, ale również przedstawia wnikliwą analizę sytuacji. Temat ten omówiono w Części III: „Katechizacja w Kościołach partykularnych”, rozdziale II: „Katecheza wobec współczesnych scenariuszy kulturowych”, podrozdział 3: „Katecheza w różnych kontekstach społeczno-kulturalnych”, punkt zatytułowany: „Katecheza a kultura cyfrowa” i jako jeden z nielicznych podzielony tematycznie: „Charakterystyka ogólna”, „Przemiana antropologiczna”, „Kultura cyfrowa jako zjawisko religijne”, „Kultura cyfrowa 
w którym powstawały dyrektoria. Byłoby niedorzecznym oczekiwać, by Directorium Catechesticum Generale, wydane w roku 1971, poruszało tematy związane z katechezą w sieci Web 2.0. Niemniej, dokonując analizy tekstów poszczególnych dyrektoriów, można zauważyć, iż każde wyrażało określony stosunek do zdobyczy technologicznych, charakteryzujących lata, w których dokumenty powstawały. „Jednak stosunek Kościoła do pojawiających się mediów elektronicznych nie był od razu jednoznaczny i akceptujący. Można mówić o ewolucji postawy Kościoła wobec mediów: od pewnej obojętności i nieufności, przez krytyczną i ostrożną akceptację, do coraz większego zaangażowania się po stronie mediów elektronicznych jako narzędzi i sposobów ewangelizacji współczesnego świata”3. Ta ewolucja postawy Kościoła widoczna jest także w kolejno wydawanych dyrektoriach. Ich analiza pozwala zrozumieć co Autorzy dokumentów rozumieli pod pojęciami takimi jak: „środki społecznego przekazywania myśli”" , „środki społecznego przekazu”, , „środki społecznej komunikacji”" i jaką rolę według nich owe środki mogły spełniać wobec katechezy. W niniejszym artykule zostaną przedstawione wyniki analizy czterech dyrektoriów katechetycznych: Directorium catechesticum generale (1971 r.), Dyrektorium ogólnego o katechizacji (1997 r.), Dyrektorium katechetycznego Kościoła katolickiego w Polsce (2001 r.) i Dyrektorium o katechizacji (2020 r.). Analiza tych dokumentów pozwoliła na pokazanie zmiany kulturowej, która dokonała się na przestrzeni lat wydawania owych dyrektoriów; zmiany rozumienia pojęć i definicji środków medialnych przez autorów dokumentów; rozwój refleksji nad wykorzystaniem tych środków w katechezie. Ostatecznie pokazuje to ewolucję postawy Kościoła wobec mediów i wytycza współczesne zadania katechezie

\footnotetext{
a kwestie wychowawcze”, „Głoszenie i katechizacja w epoce cyfrowej”. Ponadto do tematu nawiązano w Części II: „Proces katechizacji”, rozdział VII: „Metodologia w katechezie”, podrozdział 4: "Język", punkt: „Języki i narzędzia cyfrowe”. To zestawienie umiejscowienia w danym dokumencie treści dotyczących omawianego tematu pozwala zauważyć jaką postawę wobec środków społecznego przekazu przedstawiają autorzy dyrektoriów. Jakie zagadnienia zostają zaakcentowane mocniej - czy jest to podejście dostrzeżenia istnienia takich środków, czy też podejście metodologiczne z większym lub mniejszym zaufaniem wobec ich wykorzystania, bądź zaakcentowanie przemiany społeczno-kulturowej, wpływającej także na katechezę. Warto zwrócić uwagę na wydawców danych dyrektoriów. Dyrektorium ogólne o katechizacji zostało wydane przez Kongregację ds. Duchowieństwa, natomiast Dyrektorium o katechizacji przez Papieską Radę ds. Krzewienia Nowej Ewangelizacji. To również daje sygnał do rozumienia katechezy we współczesnym świecie i nadawania jej określonego kierunku.

3 A. Lewek, Nowa Ewangelizacja w duchu Soboru Watykańskiego II, Katowice 1995, s. 110; K. Marcyński, Komunikacja religijna i media, Kraków 2016, s.105.

4 DCG 2.

5 DOK 160.

6 PDK 48.
} 
w świecie cyfrowym, która musi uznać istnienie nowej „kultury cyfrowej”, wobec której konieczny jest proces inkulturacji i dostosowania języka ${ }^{8}$.

\section{Zmiana kultury na przestrzeni lat powstawania dyrektoriów - ślad w dokumentach DCG (1971) DOK (1997) PDK (2001)}

Ważny jest kontekst kulturowy, na który zwracają uwagę poszczególne dyrektoria. Dzięki niemu można zrozumieć lepiej konkretne wskazania dotyczące roli środków społecznego przekazu w katechezie. Directorium catechesticum generale, które powstało w 1971 roku zauważa rozpoczynające się przemiany kulturowo-społeczne. W punkcie 2, powołuje się na słowa Konstytucji dogmatycznej o Kościele $w$ świecie współczesnym: „Dziś rodzaj ludzki przeżywa nowy okres swojej historii, w którym głębokie i szybkie przemiany rozprzestrzeniają się stopniowo na cały świat. (...) Tak więc możemy już mówić o prawdziwej przemianie społecznej i kulturalnej, która wywiera swój wpływ również na życie religijne"9. Następnie Dyrektorium rozwija tę myśl, wskazując przejawy tych zmian: „Dziś trzeba mieć na uwadze niezwykły zasięg środków społecznego przekazywania myśli, których oddziaływanie odbiega poza granice narodów i czyni jednostki jakby obywatelami całej ludzkiej wspólnoty"10. Dyrektorium dostrzega już procesy swoistej globalizacji, o której więcej będą wspominać następne dyrektoria. Directorium catechesticum generale zwraca również uwagę iż „tego rodzaju środki mają wielki wpływ na życie chrześcijańskie, czy to z racji przekazywanej treści, czy też z racji mentalności i sposobu postępowania, jakie zaszczepiają wśród chrześcijan". Dokonując analizy zmian społeczno-kulturalnych lat 60. i początku 70. XX wieku zauważa zagrożenia spowodowane szybszym przesyłaniem danych i treści przez środki masowego przekazu: „w przeszłości błędne opinie w zakresie wiary i chrześcijańskiego życia obejmowały na ogół mniejszy procent ludzi i bardziej niż dziś rozpowszechniały się w środowiskach intelektualnych. Natomiast obecnie zarówno postęp, jak i środki masowego przekazu sprawiają, że tego rodzaju opinie rozchodzą się szybciej i wywierają coraz większy wpływ na wiernych, zwłaszcza na młodzież, która jest narażona na wielkie niebezpieczeństwo i nierzadko jest zmuszona do przyjęcia sposobów działania i myślenia wrogich religii" ${ }^{11}$. Dostrzeżono również zwiększenie grona odbiorców konkretnych treści i poglądów, które to grono nie było wystarczająco przygotowane do ich odpowiedniej interpretacji i zrozumienia (co uprzednio czyniło grono środowisk intelektualnych). Dyrektorium zauważyło,

\footnotetext{
DK 365.

Por. DK 370.

GS 4

10 DCG 2.

11 DCG 5.
} 
że rodzi to zagrożenie manipulacji odbiorcami, którzy mogą w sposób błędny przyjmować treści im dostarczane ${ }^{12}$. W ocenie przemian kulturalno-społecznych dostrzec można ostrożność zalecaną przez Dyrektorium wobec środków masowego przekazu, ale również zachętę do nie negowania ich istnienia, a wręcz zauważenia, gdyż „tego rodzaju okoliczności wymagają odpowiednich duszpasterskich środków zaradczych"13.

O wiele więcej na temat wpływu środków społecznego przekazu na kulturę napisano w Dyrektorium ogólnym o katechizacji wydanym w 1997 roku. Dowodzi to dynamicznego rozwoju owych środków, skoro od postawy ostrożności i przyglądania się zachodzącym zmianom, przedstawia się te środki jako współczesny areopag: „pierwszym «areopagiem» współczesnym jest świat środków przekazu, który jednoczy ludzkość... Środki społecznego przekazu osiągnęły takie znaczenie, że dla wielu są głównym narzędziem informacyjnym i formacyjnym, przewodnikiem i natchnieniem w zachowaniach indywidualnych, rodzinnych, społecznych. Dlatego oprócz zastosowania licznych środków tradycyjnych, wykorzystanie środków społecznego przekazu nabrało istotnego znaczenia dla ewangelizacji i katechezy"14. Dostrzec można zauważoną przez Dyrektorium na przestrzeni 26 lat olbrzymią zmianę społeczno-kulturalną wobec rozwijającej się technologii środków społecznego przekazu, które zaczęły już w latach 90. XX wieku wpływać bardzo poważnie na zachowania społeczne, indywidualne i rodzinne: „stwierdza się także ogromny wpływ środków przekazu, które wielokrotnie, z powodów o charakterze ekonomicznym lub ideologicznym, narzucają wizję życia, jaka nie szanuje tożsamości kulturowej narodów, do których się zwracają"15. Na przestrzeni lat - jak zauważa Dyrektorium, dało się zauważyć kryzysy na drodze katechezy, które „w dużej części wyniknęły z ewolucji światowego kontekstu kulturowego"16, spowodowanego także rozwojem środków społecznego przekazu. Rozwój ten przyczynił się do zwiększenia dynamizmu przemian społeczno-kulturowych. W opisywaniu rzeczywistości tamtego okresu Dyrektorium umieściło refleksję dotyczącą ówczesnej sytuacji: „Wiele wspólnot chrześcijańskich jest wezwanych do życia w świecie pluralistycznym i zeświecczonym, gdzie można spotkać formy niewiary i obojętności religijnej, ale także żywe formy pluralizmu kulturowego i religijnego; u wielu ludzi pojawia się silne poszukiwanie pewności i wartości, chociaż

12 Ciekawostką jest fakt dotyczący daty wydania Directorium catechesticum generale. Dyrektorium wydano w kwietniu 1971 r., czyli miesiąc przed instrukcją duszpasterską Communio et progessio, która „Zdaniem znawców tematu jest pierwszym i pełnym wykładem teologii mediów masowych”. K. Marcyński. Komunikacja religijna i media, dz. cyt., s. 106. Zatem Dyrektorium stoi u podstaw tej instrukcji, mając swój udział w rozwoju refleksji teologicznej wobec przemian kulturowo-społecznych, wywołanych rozprzestrzeniającym się wpływem środków masowego przekazu.

13 DCG 5.

14 DOK 160.

15 DOK 21.

16 DOK 2. 
nie brakuje także fałszywych form religijnych i niepewnego przylgnięcia do wiary. Wobec tej złożonej sytuacji może się zdarzyć, że wielu chrześcijan będzie odczuwało zakłopotanie i zagubienie się, nie umiejąc sobie poradzić w różnych sytuacjach ani ocenić orędzi, jakie w nich występują, bądź porzuci regularne praktyki religijne i będzie żyło tak, jakby Bóg nie istniał, często uciekając się do zastępczych form pseudoreligijnych"17. Te cenne spostrzeżenia były niejako prorocze, zapowiadając kolejne lata bardzo szybkich przemian społecznych i kulturalnych, których obecnie jesteśmy świadkami. Pluralizm, zeświecczenie, zakłopotanie wobec wielości informacji, osamotnienie w sieci Internetu to zjawiska, które obserwujemy dziś, a których początki zauważyło Dyrektorium. Były to początki tworzenia się nowej kultury, którego to momentu nie przeoczyło Dyrektorium. Ale dopiero Dyrektorium o katechizacji z 2020 roku wspomni o przemianach antropologicznych związanych ze środkami społecznymi ${ }^{18}$.

Do tej wnikliwej oceny ówczesnego świata, nakreślonej przez Dyrektorium ogólne o katechizacji, dodatkowe spostrzeżenia odnajdziemy w dokumencie z 2001 roku, czyli w Dyrektorium katechetycznym Kościoła katolickiego w Polsce. Zauważono, że „współczesna kultura niejed nokrotnie wystawia sumienie wierzącego na próbę" ${ }^{\prime 9}$. Są to skutki moralnego zagubienia wobec wielości informacji i poglądów, które zaczęły przenikać również do kultury polskiej. Novum w kulturze naszego kraju stało się zjawisko „tworzenia nowej „kultury czasu wolnego”, w której promowane [miały być] humanizujące relacje międzyosobowe we wzajemnych i grupowych (wspólnotowych) spotkaniach"20. Warto zauważyć, że jeszcze wówczas mówiono o spotkaniach w „realu”, poza przestrzenią wirtualną. Niemniej spotkania te służyły m.in. dzieleniu się informacjami i poglądami, które docierały do konkretnych osób poprzez środki społecznego przekazu. Dokonując usystematyzowanego opisu ówczesnych przemian kulturowo-społecznych w Polsce, Dyrektorium stwierdza, że „W aktualnej polskiej rzeczywistości istnieje wiele zagrożeń dla narodowej kultury, płynących nie tylko ze ślepego naśladownictwa obcych wzorów czy ich umasowienia, ale $\mathrm{z}$ tych tkwiących $\mathrm{w}$ niej tendencji, które podają zafałszowany obraz człowieka, stanowiącego podmiot, przedmiot i cel każdej ludzkiej kultury"21. Zauważano zatem przenikanie rewolucji kulturowych krajów zachodnich i lepiej rozwiniętych do polskiej rzeczywistości, jednak ton polskiego Dyrektorium nie jest tak alarmujący jak ton Dyrektorium ogólnego o katechizacji. W postrzeganiu środków masowego przekazu polskie Dyrektorium dostrzega możliwości wykorzystania ich w katechezie jako pomocy w przekazywaniu orędzia, ale nie sygnalizuje jeszcze mocno znaczących przemian społeczno-kulturowych, których

17 DOK 193.

18 Por. DK 362-364.

19 PDK 26.

20 PDK 8.

21 Tamże. 
przyczyną byłyby środki masowe. Jest to potwierdzenie faktu, że jeszcze w 2001 roku w niewielu domach polskich rodzin można było zauważyć komputer, czy telefon komórkowy, a tym bardziej Internet bądź laptop. Stąd przemiany kulturowe dostrzegane w innych krajach na świecie nie były jeszcze zagrożeniem dla polskiego społeczeństwa. Zauważa się jedynie, że media są źródłem i przekaźnikiem wiadomości oraz informacji dla młodego pokolenia ${ }^{22}$. Niemniej brakuje w dokumencie realnych przewidywań i spojrzenia w przyszłość, która już widniała na horyzoncie. Brak ukierunkowania katechezy wobec zbliżających się i nieuniknionych przemian społeczno-kulturalnych w perspektywie czasu okazał się nieprzemyślany i błędny. Rzeczywistość pokazała, że zmiany, które przewidywało Dyrektorium ogólne o katechizacji i nawet już wcześniejsze Directorium catechesticum generale, dotarły również do Polski. Oczywiście katecheza musiała w przyszłości odpowiadać na bieżąco na dane wyzwania i czyniła to, ale pojawia się słuszne zastrzeżenie, iż byłoby rozsądniejsze umiejętne przewidywanie pewnych przemian i wyprzedzające przygotowanie planu działania wobec nich, niż ponowne wyłącznie reagowanie na rzeczywistość, która już ma miejsce.

Zmiany społeczno-kulturowe związane z rozwojem środków społecznego przekazu ,mają swoje odzwierciedlenie we wskazaniach poszczególnych dyrektoriów katechetycznych na przestrzeni lat. Dzięki temu widać wyraźnie, że Kościół nieustannie bacznie przygląda się rzeczywistości, w której istnieje i posługuje. Wpływa to na rozwój refleksji teologicznej wobec przemian współczesnego świata i tylko ta postawa polegająca na analizie, przewidywaniu i wyciąganiu wniosków wydaje się słuszna wobec misji szerzenia Chrystusowego orędzia. Najbardziej aktualne spostrzeżenia znajdują się w Dyrektorium o katechizacji i zostaną omówione w kolejnych paragrafach.

\section{Pojęcie i definicje środków społecznego przekazu, rzeczywistość rozumiana pod tymi pojęciami w DCG, DOK, PDK}

Aby jeszcze lepiej zrozumieć sytuację społeczno-kulturową, do której odnosiły się dyrektoria, należy zauważyć, co rozumiano pod pojęciami „środków społecznego przekazu". Gdyż na inne elementy zwracano uwagę w 1971 roku, a na inne w 2001 roku.

Directorium catechesticum generale używa różnych pojęć: „środki społecznego przekazywania myśli”"3, „środki społecznego przekazu”24, „pomoce

\footnotetext{
22 Por. PDK 47.

23 DCG 2.

24 DCG 9, 131.
} 
audiowizualne”25, „środki masowego przekazu”26, „środki audiowizualne”27. Należy zadać pytanie, jaką rzeczywistość rozumiano pod tymi pojęciami. W punkcie 123. odnajdujemy swoistą definicję: „Tzw. środki masowego przekazu sprawiają między innymi to, że nadają cech rzeczywistości i aktualności faktom, instytucjom i ideom, o których mówią oraz, przeciwnie, pomniejszają w powszechnej ocenie znaczenie tych rzeczy, o których milczą" ${ }^{28}$. Jest to definicja ukazująca wpływ i możliwości środków społecznego przekazu, którymi w 1971 roku były prasa, radio, telewizja. Zwracano uwagę również na kino i rolę filmu ${ }^{29}$. Definicję środków audiowizualnych znajdziemy w punkcie 122. tego Dyrektorium: „Środki audiowizualne stosuje się zwłaszcza: a) jako dokumentację dla wzbogacenia katechezy elementami obiektywnymi. W tym wypadku mają się wyróżniać autentycznością, pilną selekcją wiadomości i przejrzystością dydaktyczną; b) jako obrazy dla właściwego kształcenia uczuć i wyobraźni. Winny się przeto odznaczać pięknem i skutecznością w uszlachetnianiu ducha"30. Uznawano je jako jedną z głównych pomocy katechetycznych $^{31}$. Pod tym pojęciem rozumiano przede wszystkim dzieła sztuki, takie jak obrazy, figury, posągi; ale również elementy graficzne ukazujące się w prasie, czasopismach, czy też przygotowywane samodzielnie przez nauczycieli pomoce w dydaktyce audiowizualnej.

Oczywiście większe spectrum możliwości stwarzały środki społecznego przekazu i pomoce audiowizualne w roku wydania Dyrektorium ogólnego o katechizacji. W dokumencie tym znajdziemy pojęcia takie jak: „środki masowego przekazu”32,

25 DCG 116, 122.

26 DCG 123.

27 DCG 124.

28 DCG 123.

29 „Kiedy pojawił się obraz filmowy, Pius XI napisał trzy encykliki: Divini Illius Magistri z 1929 roku, Casti connubii z 1930 oraz Vigilanti cura z 1936 roku, w których mówił m.in. o wpływie filmu i radia na życie rodzinne oraz zareagował potępieniem i ostrzeżeniem wiernych przed niebezpieczeństwem demoralizacji, jaką niesie przekaz filmowy. Pierwszą encykliką, w której najpełniej został przedstawiony stosunek i nauka Kościoła na temat mediów elektronicznych: filmu, radia i telewizji była encyklika Piusa XII Miranda prorsus z 1957 roku. To właśnie w tym dokumencie papież określił media jako „dar Boży”. Wyraził tym samym, że media z natury są dobre i to dobro można realizować prze trzy główne funkcje mediów: informacyjną, formacyjną i rozrywkową (...). Poświęca w niej prawie 90 wypowiedzi „filmowi idealnemu”, a więc takiemu, który wspiera rodzinę, wzmacnia państwo i szanuje Kościół. Encyklika Jana XXIII Mater et Magistra stała się inspiracją dla soborowego dekretu o środkach przekazywania myśli z 1963 roku Inter mirifica. Dekret ten stanowi pierwszy dokument, w którym całościowo ujęto wszystkie środki komunikowania społecznego". K. Marcyński. Komunikacja religijna i media, dz. cyt., s. 106. Na tym tle powstałych dokumentów możemy zrozumieć mentalność autorów Directorium catechesticum generale, ich stanowisko i rozumienie środków społecznego przekazu.

30 DCG 122.

31 Por. DCG 116.

32 DOK 160, 162. 
„Środki przekazu”33, „środki społecznego przekazu”34, „środki audiowizualne”35, „urządzenia audiowizualne”36. Ich rozumienie znajdziemy w punkcie 160 . tego Dyrektorium: „Kościół byłby winny przed swoim Panem, gdyby nie używał tych potężnych pomocy, które ludzki umysł coraz bardziej usprawnia i doskonali. (...) Mogą to być, chociaż z różnych racji: telewizja, radio, prasa, płyty, taśmy magnetofonowe, wideo i audiokasety, dyski kompaktowe, cały sektor urządzeń audiowizualnych"37. To wyliczenie pokazuje, jak na przestrzeni 26 lat od poprzedniego Dyrektorium znacząco rozwinęły się środki społecznego przekazu. Wśród urządzeń audiowizualnych w latach 90. XX w. możemy wymienić telewizory, magnetofony, magnetowidy, projektory do wyświetlania przeźroczy. Nie ma jeszcze w Dyrektorium wzmianki o Internecie, gdyż pierwsza przeglądarka WWW, umożliwiająca oglądanie graficznych stron powstała w 1993 r., natomiast rok 1997 to oficjalna premiera PHP, JavaScript, zarejestrowanie domeny Google.com, powstanie pierwszej gry MMO - z wykorzystaniem Internetu - Ultima Online, powstanie pierwszego mobilnego urządzenia $z$ Internetem - Nokia 9000i Communicator; zatem były to początki Internetu, który jeszcze w tamtym czasie nie był ogólnodostępny.

Dyrektorium katechetyczne Kościoła katolickiego w Polsce w swojej terminologii posługuje się pojęciem: „środki społecznej komunikacji”" ${ }^{38}$ i nie używa innych pojęć, jak „środki społecznego przekazu”, czy „środki audiowizualne”. Rozumienie rzeczywistości ukrytych pod używanym pojęciem jest podobne do rozumienia Dyrektorium Ogólnego o Katechizacji. Polskie dyrektorium zaleca: „Należy popierać przede wszystkim tworzenie takich materiałów dydaktycznych, zwłaszcza podręczników katechetycznych, które będą posiadać swoistą obudowę medialną w postaci kaset audio i video oraz programów komputerowych" ${ }^{\text {"3 }}$. Nowymi środkami, które zostały wymienione w tym dyrektorium są programy komputerowe, wówczas wciąż bardzo dynamicznie się rozwijające. Od wydania Dyrektorium ogólnego o katechizacji w 1997 r. do wydania Dyrektorium katechetyczne Kościoła katolickiego w Polsce w 2001 r. historia komputerowych systemów operacyjnych była świadkiem powstania „Windows 98”, „Windows 98 SE”, „Windows 2000”, „Windows Millenium Edition”, a w październiku 2001 r. - „Windows XP”. Wiązało się to z coraz większymi możliwościami komputerów, był to również czas zdobywania coraz większego zasięgu przez sieć Internetu.

$\mathrm{Na}$ przestrzeni lat zmieniało się pojmowanie środków społecznego przekazu i środków audiowizualnych, do których dopisywano kolejne zdobycze

\footnotetext{
3 Tamże.

34 DOK 160-162, 209, 269.

35 DOK 160, 266, 283.

36 DOK 160.

37 Tamże.

38 PDK 7, 48.

39 PDK 48.
} 
technologiczne. Niemniej należy dostrzec, że Kościół w wydawanych dyrektoriach nie ignorował znaczenia tych urządzeń i możliwości, które stwarzały one dla katechezy.

\section{Zalety środków społecznego przekazu i zagrożenia, jakie ze sobą niosą, dostrzegane na przestrzeni lat przez DCG, DOK i PDK}

W dyrektoriach znajdziemy również zauważane przez Autorów zalety i możliwości, które stwarzały środki społecznego przekazu. Directorium Catechesticum Generale zwraca uwagę na możliwości komunikacji wykraczające poza granice państw i narodów: „Dziś trzeba mieć na uwadze niezwykły zasięg środków społecznego przekazywania myśli, których oddziaływanie odbiega poza granice narodów i czyni jednostki jakby obywatelami całej ludzkiej wspólnoty"40.

Temat komunikacji mocno rozwija Dyrektorium ogólne o katechizacji i odnosi swoje spostrzeżenia do środków społecznego przekazu: „Ze względu na wewnętrzne znaczenie, zarówno w tradycji, jak i aktualności katechetycznej, na przypomnienie zasługują: (...) metoda komunikacji przez środki społecznego przekazu"41. Dyrektorium zauważa, że „Bóg ukazuje się jako Ten, który chce komunikować siebie, czyniąc osobę ludzką uczestnikiem swojej Boskiej natury”42. Dlatego „metodologia katechetyczna [która ma na celu] wychowanie wiary; wykorzystuje w katechezie nauki pedagogiczne i nauki o komunikacji" ${ }^{43}$. Stąd duże znaczenie mają środki audiowizualne, zwłaszcza oddziaływujące na zmysły, gdyż „przekaz wiary w katechezie (...) wyraża się przez znaki zmysłowe i ostatecznie otwiera na misterium" ${ }^{44}$. To oddziaływanie na zmysły wpływa na zaangażowanie osób katechizowanych, gdyż, jak zauważa Dyrektorium: „czynne uczestniczenie osób katechizowanych $\mathrm{w}$ procesie formacyjnym jest $\mathrm{w}$ pełni zgodne nie tylko $\mathrm{z}$ autentyczną komunikacją ludzką, lecz szczególnie z ekonomią Objawienia i zbawienia" ${ }^{45}$. Natomiast proces pobudzania osób katechizowanych do większej aktywności i zaangażowania wpływa pozytywnie na budowanie relacji między katechetą i katechizowanymi, ponieważ dla katechezy „istotne (...) znaczenie ma osobowa relacja katechety z osobą katechizowaną. Karmi się ona (...) rozwijaną kreatywnością, przystosowaniem..."46. Kreatywność katechety, polegająca na umiejętnym wykorzystaniu środków społecznego przekazu i środków audiowizualnych, może pobudzić do

\footnotetext{
40 DCG 2.

${ }^{41}$ DOK 149.

42 DOK 36.

43 DOK 148

44 DOK 150

${ }^{45}$ DOK 157.

46 Tamże.
} 
czynnego uczestnictwa katechizowanych i wpłynąć na skuteczność w realizowaniu zadań katechezy, gdyż Kościół znajduje w środkach społecznej komunikacji „nowe i skuteczne formy świętego oddziaływania, współczesną ambonę; poprzez nie może przemawiać do rzesz" ${ }^{47}$.

Podobną opinię przedstawia Dyrektorium katechetyczne Kościoła katolickiego $w$ Polsce w punkcie 48.: „Nie można zaniedbać również tych możliwości, jakie stwarzają katechezie, zwłaszcza w realizacji funkcji nauczania, środki społecznej komunikacji"48. Dyrektorium akcentuje dodatkowo wpływ tych środków na ewangelizację: „W korzystaniu w katechezie ze środków społecznej komunikacji trzeba (...) pamiętać o szansie, jaką one stwarzają dla ewangelizacji”"49.

Niemniej, obok wielu szans i możliwości, które niosą ze sobą środki społecznego przekazu, wszystkie dyrektoria zwracają uwagę również na zagrożenia wypływające z ich korzystania. Directorium catechesticum generale zauważa, że „naukowa, techniczna, przemysłowa i urbanistyczna forma cywilizacji nierzadko odwraca zainteresowanie ludzi od spraw religijnych i utrudnia wewnętrzną troskę o sprawy wiary" ${ }^{\prime 50}$. Dlatego ważne jest, jak podkreśla Dyrektorium katechetyczne Kościoła katolickiego w Polsce, aby środki społecznej komunikacji „nie zasłaniały i nie utrudniały realizacji głównych celów katechetycznych. Możliwości techniczne mediów nie mogą przesłonić prawdziwego orędzia Ewangelii, którym jest Jezus Chrystus wczoraj, dziś, ten sam na wieki (Hbr 13,8) Stąd w korzystaniu ze środków społecznej komunikacji należy zachować ostrożność i roztropnośc" ${ }^{51}$. Dyrektorium ogólne o katechizacji zauważa negatywny wpływ środków społecznego przekazu na kulturę: „W wielu miejscach traci się żywą świadomość, że kultury tradycyjne są atakowane przez dominujące wpływy zewnętrzne..."52. Tę myśl rozwija Dyrektorium katechetyczne Kościoła katolickiego w Polsce, zwracając uwagę na podważanie autorytetów i relatywizm propagowane przy użyciu środków społecznego przekazu: „Niepokój budzą propagowane, głównie w środkach społecznego przekazu, te tendencje obecne w kulturze i życiu społecznym, które podważają autorytet wychowawczy rodziców i nauczycieli w formacji młodego pokolenia oraz relatywizują tradycyjne wartości i zasady życia oparte na Ewangelii, tudzież oparty na nich system wychowania katolickiego" ${ }^{33}$.

Czytając dyrektoria, można zauważyć, że pomimo zalecanej ostrożności i roztropności w korzystaniu ze środków społecznego przekazu i wskazaniu realnych zagrożeń, które ze sobą niosą przeważa jednak tendencja zauważania olbrzymiego

\footnotetext{
47 EN 45. Por. DOK 160.

48 PDK 48.

49 Tamże.

50 DCG 5.

51 PDK 48.

52 DOK 21

53 PDK 7.
} 
potencjału i możliwości, które te środki stwarzają dla katechezy. Rodzi to odpowiednie zadania i wnioski dla katechezy, które wypływają z tej analizy.

\section{Zadania, założenia i wnioski wypływające dla katechezy i katechetów z przeprowadzonej refleksji nad środkami społecznego przekazu w DCG, DOK, PDK}

Po dostrzeżeniu wpływu środków społecznego przekazu na kulturę, oraz określeniu szans i zagrożeń, które niosą ze sobą, dyrektoria określają cele i zadania, jakie stoją przed katechezę w wykorzystaniu tych środków.

Cel podstawowy w wykorzystywaniu środków społecznego przekazu określiło Directorium catechesticum generale: „(...) zawsze trzeba na to zwracać szczególną uwagę, ażeby proponowane środki zawsze odpowiadały celom duchowym, które winny być osiągnięte" ${ }^{34}$. Dyrektorium wskazuje zadania, jakie stoją przed katechezą: „oto środki wspaniałe i bardzo ważne dla osiągnięcia pozytywnego skutku: podejmować tradycyjne formy przekazywania słowa Bożego i popierać rozwój nowych form, (...) udoskonalać tradycyjne formy chrześcijańskie i poszukiwać nowych sposobów, zebrać wszystkie aktualne pomoce Kościoła, a jednocześnie unikać form mniej odpowiadających Ewangelii. (...) odnowiona katechetyka winna posługiwać się środkami jakich mogą dostarczyć (...) środki służące dziś do rozpowszechniania myśli i poglądów, zwłaszcza środki społecznego przekazu"55. Podobny pogląd wyraża Dyrektorium ogólne o katechizacji: „Powinno się myśleć o odpowiedniej służbie na rzecz wiary dla każdego z środowisk [katechetycznych] (...) opracowując odpowiednie pomoce, odwołując się do bogatych możliwości środków społecznego przekazu..."56.

Jednocześnie Dyrektorium zwraca uwagę, że nie należy skupiać się tylko na samych środkach jako narzędziach, ale także zwrócić uwagę na osoby, które są autorami tych środków bądź ich użytkownikami (katecheci) i odbiorcami (katechizowani): „Orędzie zbawienia winno mieć swoje miejsce wśród społecznych środków przekazywania myśli ludzkiej. Dlatego nie wystarcza doskonalenie środków, jakimi dysponuje Kościół na tym odcinku, lecz zachodzi również konieczność popierania współpracy między producentami, pisarzami i twórcami scenicznymi, którzy zajmują się tymi sprawami. [Trzeba pamiętać, co rozumiano pod pojęciem środków społecznego przekazu w 1971 r. $]^{57}$. Taka współpraca domaga się utworzenia w zasięgu krajowym lub międzynarodowym, zespołów fachowców. Mogą być one rzeczywiście pożyteczne, gdy się zasięga ich opinii co do programów działania,

\footnotetext{
54 DCG 105.

55 DCG 9.

56 DOK 192.

57 Uwaga autora artykułu.
} 
dotyczącego religii. Jest również zadaniem katechezy wychowanie wiernych, by umieli oceniać charakter i znaczenie rzeczy przedstawianych za pośrednictwem środków masowego przekazu. Jest rzeczą zrozumiałą, że wymaga to uprzedniego technicznego zapoznania się ze sposobem przedstawiania myśli właściwym tym środkom przekazu" ${ }^{58}$. W podobnym tonie wypowiada się Dyrektorium ogólne o katechizacji: „Dobre wykorzystanie środków społecznego przekazu wymaga od pracujących w katechizacji poważnej troski o poznanie, kompetencję oraz umiejętne i aktualne wykorzystanie" ${ }^{59}$. Dyrektorium ogólne o katechizacji wskazuje na konkretne grupy społeczne: „Pracownicy środków społecznego przekazu i ich odbiorcy powinni mieć możliwość otrzymania łaski Ewangelii. Mobilizuje to katechetów do zwrócenia uwagi na szczególne kategorie osób: pracowników środków społecznego przekazu, (...) rodziny, (...) młode pokolenia, które są tak odbiorcami, jak i twórcami środków masowego przekazu" ${ }^{" 60}$. Według Dyrektorium Ogólnego wobec każdej z tych grup należy podjąć odpowiednie działania. Pracownikom środków społecznego przekazu ukazywać Ewangelię ,jako wielki horyzont prawdy, odpowiedzialności, natchnienia" ${ }^{61}$. Wobec rodzin, które są „bardzo wystawione na wpływ środków społecznego przekazu" "22, podjąć działania o charakterze obronnym, chroniąc je przed złym wpływem tych środków, a jednocześnie wyrobić w nich większą zdolność krytyczną i wychowawczą ${ }^{63}$. „Przypomina się wszystkim, że $\mathrm{w}$ posługiwaniu się środkami przekazu oraz $\mathrm{w}$ ich odbiorze należy pilnie zatroszczyć się z jednej strony o czynne wychowanie zmysłu krytycznego, ożywianego umiłowaniem prawdy, z drugiej - o podejmowanie Oborny wolności i poszanowania godności osoby..."64. Dyrektorium Ogólne określa również zadania wobec samych katechetów: „Formacja troszczy się o uczynienie katechetów zdolnymi do przekazywania Ewangelii tym, którzy pragną powierzyć się Jezusowi Chrystusowi. Cel formacji wymaga, aby katecheta został lepiej przygotowany do realizowania aktu przekazu..." ${ }^{65} \mathrm{z}$ wykorzystaniem środków społecznej komunikacji i środków audiowizualnych. Zadania, które postawiły dyrektoria, znaczą o bardzo poważnym traktowaniu środków społecznego przekazu i ich wpływie na kształt katechezy i kultury w ogóle.

Directorium catechesticum generale postawiło również zadania wobec środków audiowizualnych, ich twórców i katechetów, którzy z nich korzystają: „ - popierać studium na temat kryteriów, które trzeba mieć na uwadze przy produkcji i selekcji tych środków, uwzględniając szczególne aspekty orędzia chrześcijańskiego, jakie

\footnotetext{
58 DCG 123.

59 DOK 161.

60 DOK 162.

61 Tamże.

62 Tamże.

${ }^{63}$ Por. tamże.

64 Tamże.

${ }^{65}$ DOK 235.
} 
mają być przedstawione oraz zespoły osób, dla których są przeznaczone; - wychowywać katechetów do słusznej oceny tych ośrodków (często bowiem zdarza się, że katecheci nie znają właściwego charakteru mowy za pomocą obrazów; znacznie częściej zdarza się również, że środki audiowizualne źle zastosowane nie wyrażają czynnej postawy, lecz bierną; itd.)" "66. Jest to ważne spostrzeżenie Dyrektorium, aktualne również dzisiaj, uczulające katechetów, aby środki audiowizualne, czy środki społecznego przekazu nie były jedynymi środkami wykorzystywanymi podczas katechezy, czy wręcz zastępującymi aktywność i zaangażowanie samego katechety. Do tej wypowiedzi dołącza swoje spostrzeżenia Dyrektorium ogólne o katechizacji, podając wytyczne, którymi należy kierować się w dokonywaniu wyboru i oceny środków audiowizualnych: „Kryterium inspirującym tych narzędzi roboczych powinna być podwójna wierność Bogu i osobie ludzkiej, która jest podstawowym prawem życia Kościoła. Chodzi tu o umiejętność połączenia doskonałej wierności doktrynalnej z głębokim przystosowaniem do człowieka, przy uwzględnieniu psychologii wieku i kontekstu społeczno-kulturowego, w jakim on żyje. Można krótko powiedzieć, że te narzędzia katechetyczne powinny: - być związane z konkretnym życiem tych ludzi, dla których są przeznaczone i których wewnętrzne troski, pytania, walki i nadzieje mają być bezpośrednio uwzględnione" ${ }^{37}$. Dlatego ważne jest aby „katecheta znał odpowiednio (...) adresata, który otrzymuje [orędzie], jak również kontekst społeczny, w którym żyje" ${ }^{\text {"68 }}$.

Ponadto Dyrektorium zwróciło uwagę na wówczas nową w dydaktyce metodę: "Istruzione program mata” - „wychowanie zaprogramowane”69. Zachęciłoby zaprosić do współpracy w zakresie opracowywania metod przekazywania prawd za pomocą obrazów „osoby biegłe w teologii, w katechezie i w dydaktyce audiowizualnej"70. Do tej wypowiedzi dołącza swoją uwagę Dyrektorium ogólne o katechi$z a c j i$, „W dobrze zaprogramowanej katechezie takie pomoce powinny więc zostać uwzględnione. Rozwijanie wzajemnej pomocy między Kościołami, by ograniczyć koszty zakupu i zastosowania, niekiedy dość wysokie, jest prawdziwą służbą na rzecz Ewangelii" ${ }^{\prime 1}$. Directorium catechesticum generale poleciło również Konferencjom przeprowadzić analizę sytuacji przy pomocy badań ${ }^{72}$. Wskazało konieczność prowadzenia badań wobec tematów relacji zachodzących między katechezą i antropologią, katechezą i środkami społecznego przekazu ${ }^{73}$. „Tego rodzaju badanie (...) winno ujawnić lepsze sposoby działania i wskazać drogę ich podjęcia (...) i poparcia nowych. Chodzi bowiem o przewidywanie i przygotowanie tego wszystkiego, co

66 DCG 122.

${ }^{67}$ DOK 283.

68 DOK 238.

69 DCG 124.

70 Tamże.

71 DOK160.

72 Por. DCG 99-102.

73 Por. DCG 131. 
należy koniecznie podjąć w przyszłości. (...) Dlatego pracownicy Ewangelii mają się uczyć odkrywać możliwości, jakie otwierają się dla ich działalności duszpasterskiej w nowej i odmiennej sytuacji”" ${ }^{\text {"S }}$. Sytuacja ta związana była wówczas również z coraz większym wpływem środków społecznego przekazu na społeczeństwa i koniecznością dostosowania katechezy do zmieniającej się rzeczywistości. Dalej Dyrektorium zaznacza, że „to niełatwe zadanie stojące przed katechezą, musi być pełnione pod nadzorem Nauczycielskiego Urzędu Kościoła, do którego należy (...) czuwanie nad tym, by posługa słowa używała właściwych sposobów wypowiadania się"75, również z użyciem środków społecznego przekazu. Ostatecznym wniosek Dyrektorium wobec środków społecznego przekazu został wyrażony w punkcie 3.: „Wiary nie powinno się oddzielać od wspomnianego postępu, choć związany jest on z licznymi odchyleniami"76, gdyż „katecheza sama przez się suponuje globalne przyjęcie Ewangelii Chrystusa głoszonej przez Kościół" "77. To globalne przyjęcie zobowiązuje katechezę do wykorzystywania tych środków, które potrafią oddziaływać na skalę globalną. Ponadto jak zauważa Dyrektorium ogólne o katechizacji: „katecheza (...) stara się uzdolnić uczniów Jezusa do obecności, jako chrześcijan, w społeczeństwie, w życiu zawodowym, kulturowym i społecznym"78, ucząc właściwych postaw wobec środków społecznej komunikacji i w pracy z tymi środkami.

Do wyżej wymienionych zadań, na które wskazywały (w różnym stopniu, niejako uzupełniając się) Directorium catechesticum generale i Dyrektorium ogólne o katechizacji to ostatnie dodaje nowe, jakim jest troska o powołania kapłańskie i zakonne przy wykorzystaniu środków społecznej komunikacji: „Jest także ważne wykorzystanie każdego środka, by wzbudzić powołania kapłańskie i szczególne poświęcenie się Bogu w różnych formach życia zakonnego i apostolskiego oraz zapalić w sercach specyficzne powołanie misyjne"79. Ponadto proponuje, aby Konferencja Episkopatu zajęła się współpracą ze środkami społecznego przekazu ${ }^{80}$, natomiast Referat katechetyczny ma pomóc w opracowaniu środków audiowizualnych ${ }^{81}$. Dyrektorium katechetycznego Kościoła katolickiego w Polsce nie wymienia nowych zadań dla katechezy wobec środków społecznego przekazu. Ponawia zadania i cele przedstawione w poprzednich dyrektoriach i omówione wyżej ${ }^{82}$.

Wiele uwagi dyrektoria katechetyczne poświęciły sformułowaniu celów, zadań i wniosków dla katechezy w związku ze środkami społecznego przekazu. Dotyczą one wypracowania konkretnych postaw wobec samych środków i ich wykorzystania,

\footnotetext{
74 DCG 102.

75 DCG 38.

76 DCG 3.

77 DCG 18.

78 DOK 86.

79 Tamże.

80 Por. DOK 269.

81 Por. DOK 266.

82 Por. PDK 48.
} 
współpracy z odpowiedzialnymi za ich tworzenie, dotarcia z katechezą do ludzi mediów, oraz odbiorców treści przekazywanych przez środki społecznego przekazu. Poleca się także opracowanie konkretnych struktur i grup, które pomagałyby w dokonywaniu selekcji i tworzeniu pomocy katechetycznych, umożliwiających właściwy przekaz orędzia ewangelicznego. Zaleca się, by nad całym procesem czuwał Urząd Nauczycielski Kościoła we współpracy z Konferencjami Episkopatów.

\section{Dyrektorium o katechizacji o katechezie w świecie cyfrowym}

Po przedstawieniu zagadnienia katechezy wobec środków społecznego przekazu, które jest pierwotne wobec katechezy w świecie cyfrowym, możemy dostrzec odpowiedni kontekst nauczania Kościoła wobec omawianych kwestii. To połączenie jest ważne, ponieważ „Dyrektorium o katechizacji stanowi kolejne, dynamiczne rozwinięcie dwóch wcześniejszych tekstów [Directorium catechesticum generale i Dyrektorium ogólne o katechizacji], z którymi zachowuje ciągłość"83. Nie można zatem odczytywać najnowszego Dyrektorium w oderwaniu od dwóch pozostałych i całego nauczania Magisterium Kościoła. Niemniej należy zwrócić uwagę na spostrzeżenia nowego Dyrektorium, gdyż są najbardziej aktualne i odnoszą się do rzeczywistości jaką przeżywamy obecnie.

\subsection{Opis sytuacji kulturalno-społecznej}

Nowe Dyrektorium, podobnie jak poprzednie, dokonuje analizy i charakterystyki współczesnego świata. Intrygujące są spostrzeżenia w odniesieniu do rozwoju środków technologicznych. Już we wstępie padają znaczące stwierdzenia: "Z głębszego spojrzenia na kontekst kulturowy wyłania się szereg nowych kwestii, do których przeżycia Kościół jest wezwany. Dwa z nich zasługują na szczególną uwagę. Pierwszym jest zjawisko kultury cyfrowej, które niesie w sobie i tę drugą konotację, tj. globalizację kultury. Jedno i drugie są tak ściśle ze sobą powiązane, że wzajemnie się determinują i są źródłem zjawisk, które ukazują radykalną przemianę ludzkiej egzystencji" " . Znaczącym jest fakt, że dla Dyrektorium dwa kluczowe zagadnienia związane są z cyfrowością, konsekwencją, której jest globalizacja. Przewidywania poprzednich dyrektoriów okazują się słuszne, gdyż stały się rzeczywistością. Dyrektorium przedstawia własny opis sytuacji kulturalno-społecznej dostrzeganej dzisiaj. Nawiązuje do przemian społecznych, które dokonywały się na przestrzeni lat. Wskazuje znaczące postępy nauki i techniki, zwiększenie możliwości życiowych i przestrzeni indywidualnej wolności, przemiany w dziedzinie ekonomii, proces mieszania się kultur i grup etnicznych poprzez zjawisko masowej

${ }^{83}$ DK, Wstęp, s. 8.

${ }^{84}$ DK, Wstęp, s. 9. 
migracji, wzrastającą zależność między naroda $\mathrm{mi}^{85}$. Niemniej dzisiaj na pierwszy plan wysuwa się zjawisko globalizacji „wzmacnianej dodatkowo przez środki masowego przekazu..." ${ }^{\text {" }}$. Dyrektorium zwraca uwagę na fakt, że „współczesna kultura jest rzeczywistością niezwykle złożoną, jako że - z uwagi na zjawisko globalizacji oraz korzystania ze środków masowego przekazu - wzrosła liczba połączeń i wzajemnych zależności pomiędzy kwestiami i obszarami, które w przeszłości można było rozpatrywać osobno, a dziś wymagają podejścia całościowego. We współczesnym świecie nieustannie zlewają się ze sobą postęp wiedzy i tendencje kulturalne, globalizacja modeli życiowych. Przy takiej złożoności świata ludzie przyjmują wobec życia i wobec wiary zróżnicowane podejście, co daje początek wyjątkowo głębokiemu i trudnemu do sklasyfikowania pluralizmowi kulturalnemu i religijnemu ${ }^{87}$. Dyrektorium nazywa to zjawisko "globalną mentalnością", która pozwala jednoczyć się ludziom różnych krajów i kultur tworząc jedną rodzinę ludzką, ale z drugiej strony „spłyca i uniformizuje, w efekcie czego ludzie często padają ofiarą anonimowych si1 ${ }^{88}$. Ponadto Dyrektorium powołuje $\operatorname{się}^{89}$ na spostrzeżenia papieża Franciszka: „żyjemy w społeczeństwie informatycznym, dostarczającym nam chaotycznie danych, wszystkich na tym samym poziomie, i w końcu prowadzi to nas do straszliwej powierzchowności w chwili postawienia kwestii moralnych"90. Fundamentalnym opisem rzeczywistości społeczno-kulturowej w odniesieniu do cyfryzacji jest punkt 359. tego Dyrektorium. „Wprowadzenie i zastosowanie na masową skalę narzędzi cyfrowych wywołało głębokie i złożone zmiany na wielu poziomach, których konsekwencje kulturalne, społeczne i psychiczne nie są jeszcze do końca wiadome"91. Mimo pewnej powściągliwości, dokument przedstawia konsekwencje już widoczne: „coraz częściej uznaje się, że media społecznościowe, szczególnie te natury cyfrowej, są de facto głównymi środkami socjalizacji, niemal zastępując tradycyjne drogi takie jak rodzina, Kościól, szkoła. Intersubiektywność, jak się wydaje, coraz bardziej rozwija się w sieciach społecznościowych, a coraz mniej w tradycyjnych przestrzeniach społecznych (...) Wiele form interakcji osobistej przekształciło się $\mathrm{w}$ wirtualne, całkowicie tłumiąc, zwłaszcza u młodych ludzi, potrzebę tradycyjnych form relacji, a przez to uniemożliwiając bezpośredni kontakt z niepokojem, wstrząsem, radością bliźniego oraz złożonością jego doświadczenia osobistego" ${ }^{\text {"2 }}$. Dyrektorium zauważa również konsekwencje dotykające przemiany kultury i tożsamości człowieka: „...środki masowego przekazu przedefiniowały podstawowy układ odniesienia człowieka,

\footnotetext{
85 Por. DK 45.

86 DK 45.

87 DK 320.

88 DK 323.

89 Por. tamże.

90 EG 64.

91 DK 359.

92 DK 369.
} 
znacząco wykraczając poza cele ściśle związane z potrzebami komunikacji [na komunikację przede wszystkim kładziono nacisk w poprzednich dyrektoriach] ${ }^{93}$. (...) Przemiana dotyka zatem sfery tożsamości i wolności człowieka, jak również zdolności poznawczych i systemów uczenia się; nieuchronnie wpływa na sposób utrzymywania relacji i wreszcie zmienia samo podejście do doświadczenia wiary" ${ }^{\text {"94 }}$. W innym punkcie Dyrektorium nawiązuje do przemian w sferze komunikacji, które można nazwać przemianami kulturowymi: „Dogłębne zmiany w sferze komunikacji, widoczne na poziomie technicznym, wywołują zmiany kulturowe. Nowe technologie wytworzyły nową infrastrukturę kultury, która wywiera wpływ na komunikację i życie ludzi"95. Przestrzeń wirtualna stała się dla wielu, według Dyrektorium, nie mniej ważna od świata realnego, gdyż pozyskiwanie informacji i wiadomości, wypracowywanie i wyrażanie opinii, uczestnictwo w dyskusjach, poszukiwanie odpowiedzi na własne pytania przeniesiono dzisiaj do przestrzeni wirtualnej ${ }^{96}$. Oczywiście wiele konsekwencji jest dzisiaj jeszcze nie zbadanych i nie przedstawionych w wynikach badań, chociaż osobiście zapewne już przez niektórych są dostrzegalne. Charakteryzując współczesność odnośnie zjawiska cyfryzacji dyrektorium zauważa, że nie ogranicza się to tylko do obecności środków technologicznych ${ }^{97}$, oczywiście o wiele bardziej rozwiniętych niż w 1997 roku, kiedy powstało poprzednie dyrektorium, wobec których trzeba przyjąć konkretne postawy, ale, że ich oddziaływanie stworzyło nową kulturę, a wraz z nią przemianę antropologiczną ${ }^{98}$. Obecność środków technologicznych w życiu młodych ludzi jest przyjmowana jako zwyczajna, stała i całkowicie naturalna ${ }^{99}$. To zmienia sposób postrzegania współczesnego człowieka, który w przeciwieństwie do starszych pokoleń, urodził się w obecności środków technologicznych i nie był, jak starsze pokolenie, świadkiem dynamicznych przemian, które dokonały się na przestrzeni około sześćdziesięciu, pięćdziesięciu lat ${ }^{100}$. „Cyfrowość zatem nie tylko jest częścią dotychczasowych kultur, ale narzuca się jako nowa kultura, zmieniająca przede wszystkim język, kształtująca mentalność i ustawiająca nową hierarchię wartości [czasem też usuwającą jakąkolwiek hierarchię wartości] ${ }^{101}$. Dzieje się to w skali globalnej, ponieważ zniesienie odległości geograficznych poprzez wszechobecne stosowanie urządzeń połączonych w sieć dotyczy ludzi we wszystkich częściach świata"102. To, co poprzednie dyrektoria wskazywały jako zagrożenie i przewidywa-

\footnotetext{
93 Uwaga autora artykułu.

94 DK 47.

95 DK 213.

96 Tamże.

97 Por. DK 359.

98 Por. DK 359, 362.

99 Por. DK 359.

${ }^{100}$ Por. DK 359, 362.

${ }^{101}$ Por. DK 368.

${ }^{102}$ DK 359.
} 
nia, w obecnym dyrektorium zostaje określone jako charakterystyka rzeczywistości, którą przeżywamy. Zmiana na niespotykaną skalę dynamizmu, która charakteryzuje czas 23 lat pomiędzy Dyrektorium ogólnym o katechizacji a Dyrektorium o katechizacji, jest znacząca dla kształtu i zadań katechezy.

W nakreślaniu i próbie opisu współczesnych zjawisk połączonych z cyfryzacją, nowe Dyrektorium dokonuje odważnej oceny, nazywając ją „przemianą antropologiczną", związaną z nową kulturą cyfrową. Jesteśmy świadkami zderzenia się dwóch rodzajów ludzi: „digital native” (cyfrowych tubylców) oraz „digital immigrants" (cyfrowych imigrantów) ${ }^{103}$. Pierwsza grupa to pokolenie, które wyrosło w towarzystwie cyfrowych technologii i w „społeczeństwie wielkoekranowym”, uważając technologie za naturalny element ich życia i doskonale się nimi posługuje $^{104}$. Charakterystykę cyfrowego tubylca możemy odnaleźć w punkcie 363. Obraz przedkłada on nad słuchanie. Jest ukształtowany przez konsumpcję medialną, jakiej jest poddawany, co niestety ogranicza rozwój umiejętności krytycznego myślenia. Sposób pojmowania i komunikowania wyrażają takie cechy jak: wielozadaniowość, hipertekstualność, interaktywność. Zdolności analityczne ustępują miejsca intuicyjnym i emocjonalnym ${ }^{105}$. Ich wypowiadanie się charakteryzuje spontaniczność, interaktywność, partycypacja ${ }^{106}$. Ale mimo to „nowe pokolenia nie zawsze są odpowiednio przygotowane i z kulturowego punktu widzenia wyposażone do zmierzenia się z wyzwaniami społeczeństwa cyfrowego"107. Z kolei „obok takich ludzi istnieją - i to często w charakterze ich wychowawców, nauczycieli czy katechetów - osoby urodzone przed epoką cyfrową (cyfrowi imigranci), którzy w ten świat wkraczali stopniowo. Zasadnicza różnica pomiędzy tymi ludźmi polega na odmiennym mentalnym podejściu do nowych technologii i ich wykorzystania"108. To jest przyczyną coraz większej przepaści międzypokoleniowej, u podstaw której stoi niezrozumienie. Efektem tego jest wzajemne oddalanie się owych dwóch pokoleń (tubylców i imigrantów), co rodzi zagrożenie, iż pokolenie tubylców pozostanie bez wychowawców i przewodników, a pokolenie imigrantów pokona samotność i opuszczenie. Nowa kultura cyfrowa charakteryzuje się błyskawicznością, chwilowością i słabością pamięci. Efektem tego jest brak perspektyw i spojrzenia całościowego ${ }^{109}$. Dyrektorium podjęło również refleksję nad sposobem funkcjonowania mediów, które uważane były w latach 70. ubiegłego wieku za przekaźnik informacji, a dzisiaj zmieniły swoje funkcjonowanie. „Media ze swej natury raczej ukazują selektywną wizję świata niż dają bezpośredni do niego dostęp, łącząc

\footnotetext{
${ }^{103}$ Por. DK 362.

${ }^{104}$ Por. tamże.

${ }^{105}$ Por. DK 363.

${ }^{106}$ Por. DK 362.

${ }^{107}$ DK 368.

${ }^{108}$ DK 362.

${ }^{109}$ Por. DK 368.
} 
różne języki w ramach jednego przekazu, który bezzwłocznie rozpowszechniany jest w skali globalnej"110. Wobec tego zjawiska Dyrektorium wskazuje na jeszcze jedną grupę ludzi - cyfrowych analfabetów: „Wobec potoku cyfrowych wytworów współczesnymi analfabetami będą ci, którzy nie potrafią rozróżnić, pod względem jakości i prawdziwości, rozmaitych treści cyfrowych, na jakie napotykają"111. Warto zauważyć, że, jak pokazuje doświadczenie, grupa cyfrowych analfabetów pojawia się zarówno po stronie cyfrowych imigrantów (wobec których wydawać by się mogło, że z racji perspektywy czasu będą potrafili prawidłowo oceniać pewne zjawiska kulturowe), jak również po stronie cyfrowych tubylców (dla których sama umiejętność posługiwania się środkami technologicznymi nie wystarcza by wypracować prawidłową ich ocenę).

Dyrektorium zwróciło uwagę także na jeszcze jedno zjawisko związane z kulturą cyfrową, odczytując ją w kluczu zjawiska religijnego, które posiada własną wizję świata, człowieka i innych stworzeń, a także określa celowość i sens istnienia: „Inwazyjność cyfrowych treści, powszechne wykorzystanie maszyn, które działają automatycznie na podstawie coraz bardziej wyszukanych algorytmów i oprogramowania, skłaniają do postrzegania całego wszechświata jako strumienia danych, do pojmowania życia i żywych organizmów jako czegoś ledwie większego od biochemicznych algorytmów, a radykalnej wersji, do przekonania, że kosmicznym powołaniem ludzkości jest stworzenie wszechogarniającego systemu przetwarzania danych”. Ponadto nowe zjawisko religijne posiada swoiste bóstwa: „(...) w relację wchodzi się z maszyną i od niej w postawie zaufania oczekuje się odpowiedzi. Tak oto tworzy się swego rodzaju uniwersalna pseudoreligia, która legitymizuje nowe źródło autorytetu i posiada wszystkie elementy obrzędu religijnego - od ofiary, przez bojaźń absolutu, aż po samo poddaństwo nowej, nieruchomej sile sprawczej, która każe się kochać, lecz sama nie kocha" ${ }^{\prime 12}$. Zmienia to układ odniesienia $\mathrm{w}$ procesie obdarzania zaufaniem i autorytetem, skoro do wyszukiwarki, czyli do „algorytmów sztucznej inteligencji lub komputera kieruje się pytania dotyczące kwestii życia prywatnego"113.

Jest to dość ciekawa i niepokojąca charakterystyka sytuacji społeczno-kulturalnej w odniesieniu do cyfrowości jaką przedstawia najnowsze Dyrektorium. Sprawdziły się nie tylko przewidywania poprzednich dokumentów, ale dynamicznie rozwijająca się sytuacja stała się problemem o charakterze globalnym, zmieniającym układy kulturalne, społeczne, polityczne, ekonomiczne i rozpoczynającym przemiany sięgające tak dalece, iż mówi się o nowej antropologii a także nowej globalnej religii. Ale również i to Dyrektorium przedstawia własne przewidywania dotyczące przyszłości. Przewiduje, że opisywane zjawiska, posiadające elementy techniczne

\footnotetext{
${ }^{110}$ DK 368.

111 Tamże.

${ }^{112}$ DK 366.

113 Tamże.
} 
i religijne, mogą w przyszłości „utworzyć kulturę globalną, kształtującą przede wszystkim sposób myślenia i to, w co wierzyć będą kolejne pokolenia młodych ludzi”114. Wydaje się, że będą to pokolenia „(...) coraz bardziej cyfrowe, a ich sposób myślenia będzie posiadał cechy globalne, za sprawą wielkich platform komunikacyjnych i ich potencjału błyskawicznego przekazu i zasięgu działania"115.

\subsection{Zalety i zagrożenia cyfrowych form komunikacji}

Dyrektorium podaje również szanse i możliwości, jakie niosą ze sobą cyfrowe formy komunikacji. Ułatwiają komunikację, zwłaszcza z młodym pokoleniem, które przyzwyczajone jest do wzbogacania pisanego tekstu językiem obrazów i dźwięków. Cyfrowe formy komunikacji są otwarte na interakcję, która wydaje się jest konieczna dzisiaj w komunikacji z cyfrowymi tubylcami ${ }^{116}$. „Technologie informacyjne i komunikacyjne, media społecznościowe i cyfrowe urządzenia ułatwiają współpracę, wspólne działanie, wymianę doświadczeń i wzajemne poznanie. Serwisy społecznościowe mogą być nie tylko narzędziem ewangelizacji, ale również czynnikiem rozwoju człowieka. Na przykład, w niektórych sytuacjach geograficznych i kulturowych, gdzie chrześcijanie czują się odizolowani, mogą one umacniać ich poczucie rzeczywistej jedności z powszechną wspólnotą wierzących" ${ }^{117}$. Punkt 360. jest wyliczeniem zalet świata cyfrowego. Wśród nich Dyrektorium wymienia: możliwości spotkań, dialogu, wymiany między ludźmi, uczestniczenie dzięki nim w życiu społeczno- politycznym i realizowanie aktywnych postaw obywatelskich; ułatwienie dostępu do informacji i wiedzy, ułatwienie obiegu niezależnych informacji, pozwalającego ujawnianie przypadków łamania prawa i chroniącego dzięki temu osoby podatne na zagrożenia; możliwości angażowania młodych ludzi $\mathrm{w}$ inicjatywy i działania duszpasterskie; poszerzanie i wzbogacanie poznawczych zdolności człowieka; wspomaganie pamięci poprzez narzędzia archiwizowania, pozyskiwania i wyszukiwania danych; poprawę możliwości wyboru poprzez cyfrowe gromadzenie danych; możliwość zebrania większej ilości danych, celem lepszego badania skutków decyzji na różne obszary ${ }^{118}$. Dyrektorium podsumowuje te zalety jako pozytywne cyfrowe wzmocnienie ${ }^{119}$.

Oprócz zalet świata cyfrowego Dyrektorium wskazuje również konkretne zagrożenia i niebezpieczeństwa, które ten świat niesie i które są już dostrzegalne. Punkt 361 zauważa, że środowisko cyfrowe jest obszarem eksploatacji, manipulacji, samotności, przemocy. Bardzo niebezpieczne zjawisko to istnienie dark web.

\footnotetext{
${ }^{114}$ DK 367.

115 Tamże.

${ }^{116}$ Por. DK 214.

117 DK 215.

${ }^{118}$ Por. DK 360.

119 Por. tamże.
} 
Media cyfrowe narażają na uzależnienie, izolację, postępującą utratę kontaktu z rzeczywistością, utrudniają rozwój autentycznych relacji międzyludzkich. Poprzez nie upowszechniają się nowe formy przemocy, określane mianem cyberprzemocy. Poprzez Internet rozpowszechniana jest pornografia i następują czynności wykorzystywania osób w celach seksualnych lub dla hazardu. Zamknięte obiegi informacji, tworzone przez osoby o podobnych poglądach i niedopuszczające konfrontacji $\mathrm{z}$ innymi opiniami, rozpowszechniają fałszywe informacje i wiadomości, celem podsycania nienawiści i uprzedzeń. Cyfrowa przestrzeń ma możliwość kreowania wypaczonej rzeczywistości, prowadząc do zaniechania troski o życie wewnętrzne, prowadząc do utraty tożsamości i korzeni, oraz proponując postawę cynizmu jako odpowiedzi na pustkę, stopniowo odczłowieczając i coraz bardziej zamykając ludzi w samych sobie ${ }^{120}$. „Dzisiejszy katecheta musi być świadom tego, że świat wirtualny odciska bardzo głęboki ślad, zwłaszcza w przypadku osób najmłodszych i szczególnie wrażliwych. Musi też zdawać sobie sprawę z tego, jak duży wpływ może to mieć na radzenie sobie z emocjami i proces budowania tożsamości" ${ }^{\prime 21}$. Negatywny wpływ mediów społecznościowych na młode pokolenie został zaakcentowany również w punkcie 245.: „Młode pokolenia znajdują się, ogólnie rzecz biorąc, pod silnym wpływem mediów społecznościowych i tzw. świata wirtualnego. Daje to możliwości, których nie miały poprzednie pokolenia, ale zarazem niesie zagrożenia. Bardzo istotne jest, by mieć na uwadze, w jaki sposób doświadczenie relacji technologicznie zapośredniczonych wpływa na pojmowanie świata, rzeczywistości i relacji międzyludzkich" ${ }^{\prime 22}$. Dyrektorium zwraca również uwagę na globalne formy kontroli poprzez media cyfrowe: „Poza tym w świecie cyfrowym działają ogromne interesy ekonomiczne, zdolne do posługiwania się formami kontroli, zarówno subtelnymi, jak i inwazyjnymi, tworząc mechanizmy manipulowania sumieniami i procesem demokratycznym"123. Należy dostrzegać te zagrożenia, by nie popaść w nieracjonalny zachwyt nad zdobyczami technologicznymi, a jednocześnie by podjąć zadania, które pojawiają się w związku z kulturą cyfrową.

\subsection{Zadania, założenia i wnioski wypływające dla katechezy i katechetów z przepro- wadzonej refleksji nad kulturą cyfrową}

Analiza sytuacji społeczno-kulturalnej oraz dostrzeżenie szans i zagrożeń, które stwarza kultura cyfrowa, wymaga przyjęcia odpowiedniej postawy. O tych postawach mówi Dyrektorium, próbując wyjść naprzeciw współczesnej złożonej rzeczywistości. Obecna sytuacja - według Dyrektorium - stanowi nie tylko wyzwanie, lecz także szansę. „Jeśliby znaleziono formy i narzędzia, które byłyby

\footnotetext{
${ }^{120}$ Por. DK 361.

${ }^{121}$ DK 216.

${ }^{122}$ DK 245

${ }^{123}$ DK 361.
} 
w stanie odkodować przesłanki antropologiczne leżące u podstaw tych zjawisk, oraz wypracowano nowatorskie sposoby ewangelizacji, można by prowadzić działania duszpasterskie o zasięgu globalnym, tak jak globalna jest kultura cyfrowa"124. Do tego ważnego zadania Dyrektorium zaprasza wspólnoty, które powinny angażować się w podjęcie wyzwania kulturowego, oraz przystosować do młodego pokolenia narzędzia cyfrowe, które są powszechnie stosowane w dydaktyce ${ }^{125}$. Oprócz dostosowania Dyrektorium zaleca również swoistą edukację medialną ${ }^{126}$, która uczyłaby krytycznego myślenia i ofiarowywała drogę dojrzewania w wartościach ${ }^{127}$. To krytyczne myślenie jest potrzebne także wobec samych środków: „Priorytetem dla katechezy jest też wychowanie do umiejętności właściwego korzystania z tych narzędzi i głębszego rozumienia kultury cyfrowej, co będzie pomagało w odróżnieniu jej aspektów pozytywnych od problematycznych" ${ }^{\text {"28. }}$. Kolejnym zadaniem jest konieczność oceny i rozpoznania, od strony praktycznej, granic ukrytego przyswajania treści, które codziennie dokonuje się w erze cyfrowej ${ }^{129}$. Oprócz zadań wobec kultury i narzędzi cyfrowych dyrektorium wskazuje na postawy wobec odbiorców i użytkowników. Szczególną uwagę poleca wobec cyfrowych tubylców, „do których zalicza się znaczna część dzieci na świecie." ${ }^{30}$, a także wobec ludzi młodych, którym duszpasterz powinien towarzyszyć w poszukiwaniu autonomii, „polegającym na odkryciu w sobie wewnętrznej wolności i Bożego wezwania, które wyróżnia [ich] ze społecznościowego stada" ${ }^{131}$, do którego należą. Rozwija tę myśl punkt 372.: „Katecheza w epoce cyfrowej winna być procesem spersonalizowanym, ale nie indywidualnym - od indywidualistycznego i samotniczego świata społecznościowego musi prowadzić do wspólnoty Kościoła, miejsca, gdzie doświadczenie Boga prowadzi do komunii i życia rzeczywiście dzielonego z innymi. (...) Ważne, by w tym zakresie pomagać odróżniać środki od celu, rozeznawać, jak nawigować w sieci, aby rozwijać się jako podmiot, a nie przedmiot, oraz jak wykraczać poza samą tylko technikę i w ten sposób, w relacji z Chrystusem, odnajdywać odnowione człowieczeństwo" ${ }^{\prime 32}$. Jest to odpowiedź wobec antropologii cyfrowych tubylców, ale również wskazanie, by Kościół nie zamknął się tylko w przestrzeni wirtualnej. Katecheza nie może się „ucyfrowić”, ale powinna wykorzystywać potencjał i zalety nowych technologii i narzędzi cyfrowych dla celów ewangelizacyjnych, by stać się "ewangelizującą obecnością na cyfrowym kontynencie"133. Należy uniknąć wir-

\footnotetext{
${ }^{124}$ DK 367.

${ }^{125}$ Por. DK 216.

${ }^{126}$ Por. DK 368.

127 Por. DK 323.

${ }^{128}$ DK 216.

${ }^{129}$ Por. DK 369.

${ }^{130}$ DK 237.

${ }^{131}$ DK 370.

${ }^{132}$ DK 372.

${ }^{133}$ DK 371.
} 
tualizacji katechezy, a jednocześnie tworzyć warunki do przeżywania religijnego doświadczenia ${ }^{134}$. „Katechizacja winna znaleźć właściwy sposób, by zmierzyć się z takimi ważnymi kwestiami, dotyczącymi sensu życia, cielesności, uczuciowości, tożsamości płciowej, sprawiedliwości i pokoju, które w epoce cyfrowej interpretowane są w odmienny sposób"135.

Podsumowaniem wskazanych zadań mogą być słowa punktu 47:: „Dla Kościoła zatem rewolucja $w$ dziedzinie środków przekazu i informacji jest wielkim i pasjonującym wyzwaniem, które wymaga świeżej energii i nowej wyobraźni, by przekazywać innym piękno Boga"136.

\subsection{Inkulturacja w kulturze cyfrowej i język cyfrowych tubylców}

Wśród zadań katechezy wobec kultury, podstawowym zawsze było zadanie inkulturacji, związane z tworzeniem odpowiedniego języka. Temat ten jest również szeroko omawiany we wszystkich dyrektoriach i zasługuje na oddzielny artykuł. W niniejszym ograniczymy się tylko do kwestii inkulturacji w świecie cyfrowym i tworzeniu języka, który byłby zrozumiany przez cyfrowych tubylców.

Warto zauważyć, że już Dyrektorium ogólne o katechizacji wskazuje na potrzebę inkulturacji wobec środków społecznej komunikacji. „Przede wszystkim jednak, ze względu na silny wpływ na kulturę, do której kształtowania przyczyniają się środki społecznego przekazu, nie należy zapominać, że nie wystarcza używać ich do szerzenia orędzia chrześcijańskiego i Magisterium Kościoła, ale trzeba włączyć samo orędzie w tę nowa kulturę, stworzoną przez nowoczesne środki przekazu (...) z nowymi językami, nowymi technikami, nowymi postawami psychologicznymi" 137 . Inkulturacja w świecie wirtualnym podlega tym samym prawom i zasadom, co inkulturacja $\mathrm{w}$ świecie realnym. Są to procesy przystosowania ${ }^{138}$. „Ewangelia kładzie nacisk na katechezę otwartą, wielkoduszną i odważną, która kieruje się do osób tam, gdzie one żyją, spotykając szczególnie te punkty węzłowe życia, w których następuje elementarna i podstawowa wymiana kulturowa (...). Jest również ważne, by katecheza umiała rozpoznać i przeniknąć $w$ te środowiska antropologiczne, w których tendencje kulturowe mają większy wpływ na tworzenie i rozpowszechnianie modeli życia (...), należą do nich obszary kulturowe, „współczesnymi areopagami", takie jak obszar komunikacji" ${ }^{139}$. Dyrektorium wspomina również o inkulturacji narzędzi, którymi posługuje się katecheza, jakimi były

\footnotetext{
${ }^{134}$ Por. tamże.

135 Tamże.

${ }^{136}$ DK 47.

${ }^{137}$ DOK 161.

${ }^{138}$ Por. DOK 170.

${ }^{139}$ DOK 211.
} 
wówczas środki audiowizualne ${ }^{140}$. Należy zwrócić uwagę na jedno z wielu zadań inkulturacji wiary, które ma znaczenie wobec kultury cyfrowej - mowa o katechezie doskonalącej, która uzdalniałaby chrześcijanina do uzasadnienia jego wiary w świecie współczesnym ${ }^{141}$, czyli dzisiaj również w wirtualnym. Ponadto Dyrektorium poleca, aby dobrze koordynować duszpasterstwo wychowania wobec samych wychowawców, „którzy zwracają się do dużej liczby adresatów, przede wszystkim do dzieci i dorastającej młodzieży"142 - dziś moglibyśmy dodać - również poprzez środki społecznego przekazu. Polskie Dyrektorium katechetyczne zwróciło uwagę na postawę katechety wobec nowej kultury: „Katecheta, pragnąc kształtować postawy zgodne z duchem Ewangelii oraz tworzyć nowy typ kultury, sam powinien być wzorem człowieka dialogu i współpracy, bezinteresowności i poświęcenia, wspomagającego rozwój religijny i osobowy ucznia. Obce są mu więc poczucie wyższości, izolacja, przeświadczenie o samowystarczalności”143.

Dyrektorium ogólne poruszyło także kwestię języka wobec współczesnych mu środków społecznej komunikacji. „Jedno z węzłowych zagadnień, jakie należy podjąć i rozwiązać, dotyczy ,języka” (mentalność, wrażliwość, gusty, style, słownictwo...) między młodymi i Kościołem (katecheza, katecheci). Kładzie się więc nacisk na konieczność „przystosowania katechezy młodych” przekładając na ich język „Z cierpliwością i mądrością orędzie Chrystusowe, nie wypaczając go"144. Według Dyrektorium ,jednym z najbardziej skutecznych i przekonujących jest język środków masowego przekazu. Sama ewangelizacja współczesnej kultury zależy w wielkiej mierze od ich wpływu. (...) przypominamy niektóre wskaźniki użyteczne dla skutecznej inkulturacji: szersze dowartościowanie środków społecznego przekazu zgodnie z ich specyficzną wartością komunikacyjną, przy dbałości o dobre zrównoważenie języka obrazu z językiem słowa; ochrona autentycznego zmysłu religijnego w uprzednio wybranych formach wyrazu; promocja dojrzałości krytycznej odbiorców i pobudzanie do osobistego pogłębienia tego, co zostało odebrane ze środków społecznego przekazu, opracowanie odpowiednich pomocy katechetycznych do wykorzystania w środkach społecznego przekazu..." ${ }^{145}$. Widać wyraźnie, że Dyrektorium odnosi się do momentu sytuacji kulturalnej, w której się znajduje, mianowicie wskazuje z jednej strony na umiejętność wykorzystania środków społecznego przekazu do inkulturacji w świecie realnym, ale z drugiej strony zaleca tworzenie umiejętności krytycznego myślenia u odbiorców treści płynących z tych środków, co wskazuje na dostrzeganie już wtedy pewnych zmian kulturowych.

\footnotetext{
${ }^{140}$ Por. DOK 283.

${ }^{141}$ Por. DOK 71.

${ }^{142}$ DOK 273.

${ }^{143}$ PDK 159.

${ }^{144}$ DOK 185; por. DOK 208.

${ }^{145}$ DOK 209.
} 
Niemniej problem, który porusza najnowsze Dyrektorium nie odnosi się do wykorzystywania środków społecznego przekazu w inkulturacji wiary w świecie realnym, ale podejmuje zagadnienie ikutluracji wiary w świecie cyfrowym, gdzie narzędzia cyfrowe nie są tylko pomocami katechetycznymi, ale rzeczywistością, w której należy zasiać ziarno Słowa Bożego ${ }^{146}$. „Kościół wezwany jest do refleksji nad specyficznym sposobem poszukiwania wiary, cechującym młodych w epoce cyfrowej, a następnie do wynikającej z niej aktualizacji własnych sposobów głoszenia Ewangelii i dostosowania ich języka do języka młodego pokolenia" ${ }^{\text {"47 }}$. Dyrektorium przewiduje, że rozpoczyna się okres, w którym „katecheza staje się nośnikiem znaczeń” ${ }^{148}$, na których opierając się można będzie budować „mniej standardowe, a bardziej nastawione na specyfikę konkretnego człowieka ścieżki dochodzenia do wiary"149. Zadanie, które wynika z tych spostrzeżeń dotyczy dostosowania katechezy, polegającego na „przełożeniu przesłania Jezusa” na język cyfrowych tubylców ${ }^{150}$. Wpierw jednak należy zrozumieć i wyjaśnić język, którym posługują się użytkownicy Internetu. Język ten bowiem nosi wielokrotnie znamiona języka religijnego ${ }^{151}$. „Samo np. wezwanie Jezusa, by być Jego uczniem, jest terminem, który należy dogłębnie wyjaśnić, by nie został czsem pomylony z procesami charakterystycznymi dla zachowań w sieci. Dynamika bycia uczniem to przecież nie to samo, co relacja, jaka nawiązuje się pomiędzy influencerem a jego wirtualnymi followersami. Do tej pierwszej potrzeba osób obdarzonych autorytetem, które poprzez osobiste towarzyszenie, będą potrafiły doprowadzić każdego z tych młodych ludzi do odkrycia jego własnego życiowego projektu. Droga taka wymaga przejścia od samotności, która karmi się internetowymi lajkami, do realizacji projektów osobistych i społecznych, które dokonują się we wspólnocie"152. Dyrektorium wysuwa propozycję języka opowieści. „Sztuka snucia opowieści (storytelling), stosująca zasady retoryki i własny, przejęty od marketingu, język, uznawana jest przez młodych ludzi za bardziej przekonującą i angażującą formę przekazu niż tradycyjne formy dyskursu. Język, który najlepiej trafia do pokolenia cyfrowego, to język opowieści, a nie argumentacji"153. Dokładna analiza tego języka została przedstawiona w 364 . punkcie Dyrektorium. Zwraca się w nim uwagę, że język ten umożliwia tylko odbiór treści, ale nie odkodowanie przekazu. Narracja, która stałaby się jedynym narzędziem komunikacji, może stworzyć zagrożenie budowania wyłącznie subiektywnych opinii o rzeczywistości. Grozi to zepchnięciem kwestii politycznych i etycznych wyłącznie do sfery osobistej i prywatnej. Norma moralna przekazywana tym językiem,

\footnotetext{
${ }^{146}$ Por. DK 371 - 372.

${ }^{147}$ DK 370.

148 Tamże.

149 Tamże.

${ }^{150}$ Por. DK 245.

${ }^{151}$ Por. DK 370.

${ }^{152}$ DK 370.

${ }^{153}$ DK 363.
} 
może zostać odebrana jako autorytarna. Wartość prawdy w narracji zostaje poddana próbie subiektywnych opinii i nie posiada egzystencjalnej wagi ${ }^{154}$. „Swiat cyfrowy i jego narzędzia stanowią potężne środki poszukiwania nowych, nieznanych dotąd form przekazu wiary, ale prawdą jest też, że Kościół poprzez swe działania musi uświadamiać możliwe ambiwalencje języka, który jest wprawdzie sugestywny, ale w niewielkim stopniu zdatny do przekazu prawdy"155. Mimo wszystko Dyrektorium zachęca, aby przyswoić sobie sposoby efektywnej komunikacji i być obecnym w sieci, gdyż ta obecność może stać się świadectwem wartości ewangelicznych ${ }^{156}$. Ale jak zauważa Dyrektorium, „rzeczywistość wirtualna nie może zastąpić rzeczywistości duchowej, sakramentalnej i kościelnej, przeżywanej w bezpośrednim spotkaniu osób" ${ }^{\prime 157}$. Istotą nie jest posługiwanie się zaawansowanymi technologiami w katechezie, choć są one pomocne. Ostatecznie to Bóg „chce się wyrażać poprzez nasze środki, nawet jeśli są ubogie, gdyż to On działa, to On przekształca, to On zbawia ludzkie życie. Aby dawać świadectwo Ewangelii, konieczna jest autentyczna komunikacja, która stanowi owoc rzeczywistej interakcji między ludźmi"158.

\section{Podsumowanie}

Analiza czterech dyrektoriów pozwoliła zauważyć opisywaną przez nich zmianę społeczno-kulturową, związaną z rozwojem technologii i środków społecznego przekazu, które od prasy, radia i telewizji w 1971 r. przekształciły się w globalne środki komunikacji cyfrowej połączone w sieci. Można również dostrzec rozwój stanowiska Kościoła wobec środków społecznego przekazu i ich wykorzystywania w katechezie. Ważnym są spostrzeżenia dotyczące zadań wynikających z omawianych kwestii, które to zadania dotyczą relacji katechezy i kultury, postawy wobec katechizowanych i nowych technologii, jak również postawy samych katechetów i odpowiedzialnych za katechizację. Inspirujące są przewidywania dyrektoriów wobec rozwijającej się dynamicznie rzeczywistości. Należy niewątpliwie podjąć wyzwanie inkulturacji wiary w kulturze cyfrowej i odnaleźć język porozumiewania się z cyfrowymi tubylcami. Podjęcie tych zadań to wzięcie odpowiedzialności za katechezę w świecie współczesnym. Dynamika przemian, które zostały pokazane w niniejszym artykule mobilizuje do dość sprawnych działań, które podjęte zbyt późno mogą okazać się już nieaktualne.

Słowa kluczowe: katecheza, kultura cyfrowa, inkulturacja cyfrowa, język cyfrowy.

\footnotetext{
${ }^{154}$ Por. DK 364.

155 Tamże.

${ }^{156}$ Por. DK 214.

${ }^{157}$ DK 217.

${ }^{158}$ Tamże.
} 


\section{Summary}

The author analyzed four catechetical directories: the Directorium Catechesticum Generale (1971), the General Directory for Catechesis (1997), the Catechetical Directory of the Catholic Church in Poland (2001) and the Directory for Catechesis (2020). The analysis of these documents made it possible to show the cultural change described by these documents, which took place over the years of their publication; changing the understanding of concepts and definitions of media media; development of reflection on the use of these resources in catechesis. The author presents the tasks concerning the relationship between catechesis and culture, attitudes towards catechized people and new technologies, as well as the attitudes of the catechists themselves and those responsible for catechesis, which were indicated by the director. Indicates the predictions of directors regarding the future related to the development of new technologies. A special task is to inculturate in the digital world and find the language of faith towards digital natives.

Keywords: catechesis, digital culture, digital inculturation, digital language catechesi, cultura digitale, inculturazione digitale, linguaggio digitale.

\section{Riassunto}

Lautore ha esaminato quattro Direttori catechetici: il Directorium Catechesticum Generale (1971), il Direttorio Generale per la Catechesi (1997), il Direttorio Catechistico della Chiesa Cattolica in Polonia (2001) e il Direttorio per la Catechesi (2020). L'analisi di questi documenti ha favorito l'esposizione del cambiamento culturale che vi è descritto e avvenuto nel corso degli anni a partire dalla loro pubblicazione; cambiamento nella comprensione dei concetti e delle definizioni dei mezzi di comunicazione; sviluppo della riflessione sull'uso di queste risorse nella catechesi. L’autore espone i compiti riguardanti il rapporto tra catechesi e cultura, gli atteggiamenti verso i catechisti e le nuove tecnologie, nonché gli atteggiamenti dei catechisti e dei responsabili per la catechesi, indicati nei direttori.

Parole chiavi: catechesi, cultura digitale, acculturazione digitale, linguaggio digitale.

\section{Bibliografia}

Franciszek, Adhortacja apostolska o głoszeniu Ewangelii we współczesnym świecie Evangelii gaudium, Rzym $2013 \mathrm{r}$.

II Sobór Watykański, Konstytucja duszpasterska o Kościele w świecie wspótczesnym Gaudium et Spes, Rzym 1965 r.

Konferencja Episkopatu Polski, Dyrektorium katechetyczne Kościoła katolickiego w Polsce, Warszawa $2001 \mathrm{r}$.

Kongregacja ds. Duchowieństwa, Dyrektorium ogólne o katechizacji, Rzym 1997 r.

Kongregacja ds. Duchowieństwa, Ogólna instrukcja katechetyczna, Warszawa 1992 r.

Marcyński K., Komunikacja religijna i media, Kraków 2016 r.

Papieska Rada ds. Krzewienia Nowej Ewangelizacji, Dyrektorium o katechizacji, Rzym $2020 \mathrm{r}$.

Paweł VI, Adhortacja apostolska Evangelii nuntiandi, Rzym 1975 r. 


\section{$O$ autorze}

Ks. Mateusz ADAMSKI - magister teologii (2017 r.) kapłan diecezji łowickiej, święcenia kapłańskie w 2018 r., student II roku Specjalistycznych Studiów Teologicznych z katechetyki na Wydziale Teologii UKSW, rezydent przy parafii św. Małgorzaty w Łomiankach. 